\title{
A Preliminary Study on the Priority of Business Evaluating Model for Design Office
}

\author{
Dae Young Kim(a) ${ }^{1}$, Nak Ku Baek² ${ }^{2}$ Dong Heon Lee ${ }^{3}$, Dae Young Kim(b) ${ }^{4}$ and Hyoung Chul Lim ${ }^{5}$ a \\ ${ }^{1}$ Pusan National University, School of Architecture Engineering, Professor, Korea \\ ${ }^{2}$ Changwon National University, School of Architecture Engineering, Master's Course, Korea \\ ${ }^{3}$ Changwon National University, School of Architecture Engineering, PhD Candidate, Korea \\ ${ }^{4}$ Kyungnam University, School of Architecture Engineering, Professor, Korea \\ ${ }^{5}$ Changwon National University, School of Architecture Engineering, Professor, Korea
}

\begin{abstract}
Considering that we are at the initial phase of application Business Process Management model, a sequential application plan must be taken for each unit task. Adapting Business Process Management into the enterprise recourse of the construction industry across all business process could cause problems due to rapid change in corporate operation systems. We finally suggested the definition of Business Process Management model by analyzing each business unit so that we could propose and generalize value chain and business process architecture suitable for design office. Furthermore, by evaluating each business unit (which is included in the business process architecture), based on quantitative standards, we presented a sequential application plan for business process model.
\end{abstract}

\section{Introduction}

Due to globalization of business environment and fierce competition, the construction industry requires management systems to increase management efficiency and corporate benefit[1]. At the same time, it is necessary to establish management strategy, increasing the value of intangible assets by collecting and analyzing real-time data so that we can take immediate and flexible reaction to cope with the changes.

Other industries noticed the changing environment in advance, actively engaging in research and discussions in order to apply BPM and to improve process-information technology separation[2]. While in the construction industry, however, only a few companies were reviewing the introduction of BPM and were limited to theoretical approach.

Considering that we are at the initial phase of application BPM model, a sequential application plan must be taken for each unit task. Adapting BPM into the enterprise recourse of the construction industry across all business process could cause problems due to rapid change in corporate operation systems. Further, it is unable to predict potential risks while BPM are being applied. Therefore, applying BPM model to the core strategy and task seems more effective than applying BPM model to the entire enterprise recourse planning. In that case, it is desirable to get

\footnotetext{
${ }^{a}$ Corresponding author : hclim@changwon.ac.kr

"This research was supported by Basic Science Research Program through the National Research Foundation of Korea(NRF) funded by the Ministry of Education(NRF-2016R1D1A1B01012129).“
} 
feedbacks about the problem in the procedure and apply it to other operations accordingly.

This paper suggests a sequential application plan by quantitative criteria of each unit task which is included in business process architecture. The procedures are as follows:

- To consider and propose an evaluation criteria for BPM model application

- To research adoption priorities for BPM model application

- To analyze the importance of each evaluation criteria for BPM model application

- To propose adoption priorities for sequential BPM model

\section{Definition BPM application}

Us Smith (2003) defined BPM, the third wave, as a well-organized and designed activity, managing and improving business processes that raise productivity and its supporting methodology and system. Weskw (2004) agreed that BPM is a methodology used to design, execute, and control operating processes related to human, organization, application, document and other information sources, or it is something that supports business processes utilizing a system. As mentioned above, definitions of BPM in the existing research are as follows (Table 1.)[3] :

Table 1. Definitions of BPM

\begin{tabular}{c|c}
\hline Author & Definitions of BPM \\
\hline $\begin{array}{c}\text { D. Jack } \\
(1995)\end{array}$ & $\begin{array}{c}\text { A structural method which analyzes, improves, controls and manages } \\
\text { processes for enhancing quality of product or service }\end{array}$ \\
\hline $\begin{array}{c}\text { Zairi, M } \\
(1997)\end{array}$ & $\begin{array}{c}\text { A structural method which analyzes, improves essential elements such as } \\
\text { production, and communication }\end{array}$ \\
\hline $\begin{array}{c}\text { M. } \\
\text { Weskw } \\
(2004)\end{array}$ & $\begin{array}{c}\text { BPM is a methodology to design, execute, control operating process related } \\
\text { man, organization, application, document and other information sources, or a } \\
\text { thing that supports business processes applying a system }\end{array}$ \\
\hline $\begin{array}{c}\text { Smith } \\
(2003)\end{array}$ & $\begin{array}{c}\text { A managing methodology supporting business procedure by designing, } \\
\text { managing and improving to raise business productivity, or its software system }\end{array}$ \\
\hline
\end{tabular}

The established definition of BPM allows the conception of enhanced effects such as a visibility of business processes, business monitoring.

However, difficulty in enterprise recourse planning and feedback followed by corporate core strategy, lack of sequential application plan and sustainable management plan through BPM were pointed as its problem.

Consequently, this paper defined BPM model application of the construction industry as:

A system to improve and visualize business process within and outside the company by applying the business process which is related to the strategy of the construction company; to execute and control human resources and systems (related to work performance) suitable to business process; to monitor and operate business processes continuously.

It is expected to realize business efficiency through business process improvement and maintaining the system by getting rid of inefficient factors.

Applying an BPM model to business strategy of construction industry requires a sequential adoption. The reason for this is that we have to get feedbacks from trial and error, and thus reduce potential risks while we apply it to other tasks.

In order to apply a sequential BPM model, analyzing the construction core strategy must be done ahead of all other procedures, and then analysis of core business tasks that could realize each company's core strategy should be followed. Then we visualize the process of each unit task to BPM's priority operations and get feedback by monitoring and measuring results so that we can get rid of the inessential factors. 


\section{How to evaluate business process}

\subsection{Analyzing business process criteria}

Lee, Byoung-ok (2004) in his research 'the BPM building strategy of manufacturing industry' suggested long-term cycle operation and operations involved in many organizations[4]. Choi, Jin-ho (2006) suggested high-strategic priority work and those which need process improvement[5]. The BPM building report of ' $\mathrm{L}$ ' company focused on the importance of business process, operations that involve number of organizations, and operations that need change and automation. The Korea Productivity Center presented work with typical disposal flow, familiar work done by large number of people, and work that is repeated across departments. Finally, the BPR report of 'B' company focused on dissatisfaction factors and operations that involve more than 30 people in one department. The business criterion for the application of BPM to the existing research is as below (Table 2.). After considering each criterion, there are two significant findings. One is efficiency when business process model adoptions occurred, and the other is something that suggests evaluation standard in easiness factor.

Table 2. Evaluation Criteria for the Application on BPM

\begin{tabular}{|c|c|c|c|}
\hline Reference & Evaluation Criteria & Efficiency & Easiness \\
\hline \multirow{8}{*}{$\begin{array}{l}\text { A study on the Case } \\
\text { of Implementing } \\
\text { BPM for a } \\
\text { Manufacturing } \\
\text { Company } \\
\text { Byung-Ok } \\
\text { Lee(2004) }\end{array}$} & An operation involved by many department & O & \\
\hline & A long-term cycle operation to complete & O & \\
\hline & $\begin{array}{l}\text { An operation apt to frequent changes on } \\
\text { guidelines and/or disciplines }\end{array}$ & & O \\
\hline & A core business of corporate & O & \\
\hline & An operation which can be easily automated & & O \\
\hline & $\begin{array}{l}\text { An operation apt to frequent changes in } \\
\text { organization and management }\end{array}$ & O & \\
\hline & $\begin{array}{l}\text { An operation to be understood of its progress } \\
\text { status }\end{array}$ & O & \\
\hline & An operation with high-frequency of occurrence & O & \\
\hline \multirow{7}{*}{$\begin{array}{l}\text { A Study on Process } \\
\text { Selection and } \\
\text { Implementation for } \\
\text { Business Process } \\
\text { Management } \\
\text { Jin-ho, Choi(2006) }\end{array}$} & $\begin{array}{l}\text { An operation of higher strategic importance } \\
\text { (relation with a strategic purpose) }\end{array}$ & O & \\
\hline & $\begin{array}{l}\text { An operation requiring urgent improving of } \\
\text { process (Business productivity, Accuracy, } \\
\text { Adequacy of cost) }\end{array}$ & & O \\
\hline & $\begin{array}{l}\text { An operation which needs to be managed and } \\
\text { monitored }\end{array}$ & O & \\
\hline & An operation which needs rapidity & O & \\
\hline & $\begin{array}{l}\text { An operation to be processed with } \\
\text { multiplication: } \\
\text { (Organization, complication of processing level) }\end{array}$ & O & \\
\hline & $\begin{array}{l}\text { Easiness of building BPM(clearness of } \\
\text { organization, possibility of supporting legacy } \\
\text { system) }\end{array}$ & & O \\
\hline & $\begin{array}{l}\text { An operation of having less risk in application } \\
\text { (relation with other process, cases) }\end{array}$ & & O \\
\hline \multirow{3}{*}{$\begin{array}{c}\text { Report of } \\
\text { Implementing BPM } \\
\text { of Company } \\
\text { 'L'(2004) }\end{array}$} & $\begin{array}{l}\text { Process importance, an operation involved by } \\
\text { many departments }\end{array}$ & O & \\
\hline & An operation which needs to be standardized & & O \\
\hline & Work needed to manage change and automation & & O \\
\hline
\end{tabular}




\begin{tabular}{|l|c|c|}
\hline $\begin{array}{l}\text { An operation which requires plenty of } \\
\text { communication }\end{array}$ & 0 & \\
\hline $\begin{array}{l}\text { An operation which needs to be enhanced for } \\
\text { speedier processing }\end{array}$ & $\circ$ & \\
\hline $\begin{array}{l}\text { An operation of strict time limit and often forced } \\
\text { control required }\end{array}$ & 0 & \\
\hline $\begin{array}{l}\text { An operation requested frequently to be } \\
\text { computerized and to be controlled in loose } \\
\text { forms }\end{array}$ & & \\
\hline
\end{tabular}

\subsection{How to evaluate sequential BPM application}

Table 3. Conceptual methods of criteria for applying BPM

\begin{tabular}{|c|c|c|}
\hline Criteria & $\begin{array}{l}\text { Evaluation } \\
\text { Point }\end{array}$ & Contents \\
\hline \multirow{3}{*}{ Efficiency } & $\begin{array}{c}\text { Corporate value } \\
\text { enhancement }\end{array}$ & $\begin{array}{l}\text { The degree of effect on corporate value and importance of the process mean work of importance } \\
\text { which enhance corporate value.. }\end{array}$ \\
\hline & $\begin{array}{l}\text { Process } \\
\text { complexity }\end{array}$ & $\begin{array}{l}\text { It indicates visualization effect on structural and non-structural works. Level of involvement in } \\
\text { the process by related departments affects complication of the Process } \\
\text { Under the circumstances of a complicated process and having difficulty to grasp and monitor } \\
\text { progressing status of work, we could manage operational process by adopting BPM. On the other } \\
\text { hand, more operational process (which is more immanent than simple-repetitive work) visualizes } \\
\text { BPM effects more significantly. }\end{array}$ \\
\hline & $\begin{array}{l}\text { Unit task } \\
\text { teamwork } \\
\text { frequency }\end{array}$ & $\begin{array}{l}\text { A basic majority-led process performed by variant subjects } \backslash \text { When lots of cooperation is needed, } \\
\text { the efficiency of the BPM application increases. }\end{array}$ \\
\hline \multirow{3}{*}{ Easiness } & IT support & Easiness of BPM application according to the level of information system built in the company \\
\hline & $\begin{array}{c}\text { Frequency of unit } \\
\text { task change }\end{array}$ & $\begin{array}{l}\text { Difficulty and irregularity of managing process due to frequent change of organization and } \\
\text { management. }\end{array}$ \\
\hline & $\begin{array}{c}\text { Sensibility of } \\
\text { external change }\end{array}$ & $\begin{array}{l}\text { The amount of environmental effects on business process resulting in many changes in law or } \\
\text { regulation. }\end{array}$ \\
\hline
\end{tabular}

Criteria for BPM application consists of Efficiency (EF) and Ease (EA). Efficiency is classified as improvement of corporate value (V), diversity of process (D), and teamwork frequency (T). Ease (EA) consists of IT support (I), frequency of unit task change (C), and sensibility of external change (S).

Conceptual methods of criteria for applying BPM are as in Table 3.

A system of Process criteria is as in Fig 1.

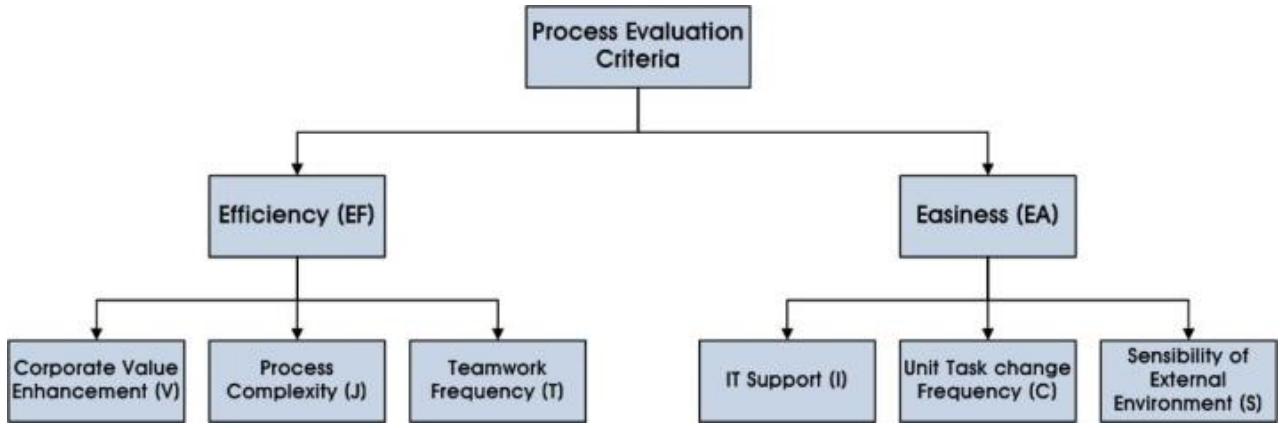

Figure 1. System of Process criteria 


\section{Analysis Method for Evaluating Business Process}

\subsection{Questionnaire outline}

Relative comparison among each criteria and evaluation of the priorities of BPM model application for each unit task were performed during the week of Feb 28, 2007 through AHP (Analytic Hierarchy Process). These surveys were asked to staff from 11 companies who were in charge of Management, HR, Processing, Finances \& economy, IT, or construction performance for at least 10 years. The return rate of the questionnaires was $75 \%$ out of 110 copies distributed and is as in Table 4.

Table 4. Questionnaires outline

\begin{tabular}{|c|c|}
\hline Criteria & Contents \\
\hline Purpose & $\begin{array}{l}\text { (1) Analyzing the importance among each criteria choosing core area for BPM } \\
\text { model application } \\
\text { (2) Evaluation the priorities of BPM model application on each unit task }\end{array}$ \\
\hline Period & 2007 2008 \\
\hline Target & $\begin{array}{l}\text { Staff who were in charge of Management, HR, Processing, Finances \& economy, } \\
\text { IT, and construction performance (11 domestic general contractors) }\end{array}$ \\
\hline $\begin{array}{l}\text { Research } \\
\text { Methods }\end{array}$ & $\begin{array}{l}\text { Step 1: To introduce the survey and to confirm the participant's consent by } \\
\text { telephone. } \\
\text { Step 2: To introduce the concept of the survey. To explain how to fill out the } \\
\text { questionnaire and to distribute personal visit. } \\
\text { Step 3: to collect it by mail or visiting. }\end{array}$ \\
\hline Return rate & $\begin{array}{l}\text { - The number of total copies : } 110 \\
\text { - Contractors }: 11 \text { companies, each } 10 \text { copies } \\
\text { - Replied copies : } 83 \\
\text { - The return rate }: 75 \%\end{array}$ \\
\hline
\end{tabular}

\subsection{Organizing questionnaire to analyze the importance of evaluation criteria}

The questionnaire for analyzing the importance of evaluation criteria for applying an BPM model is organized as follows: In terms of Efficiency and Easiness, the criteria were written on the left and right end of the sheet in order to test relative comparison and to allow respondents to mark the importance.

Meanwhile, the form for analyzing Efficiency and Easiness of an BPM model application on each unit task is as in Fig.2. The targets of each unit are the hundred tasks in the Process chain level in the business process architecture. Quantitative evaluation was carried out under an eleven-point measurement.

\section{Priority analysis result by applying sequential BPM model.}

\subsection{Analysis result of the importance of each criteria}

Through the relative comparison of each evaluation criteria, we analyzed the importance of evaluation criteria and performed CR (Consistency Reliability) under the result suggested by Satty (1980). 


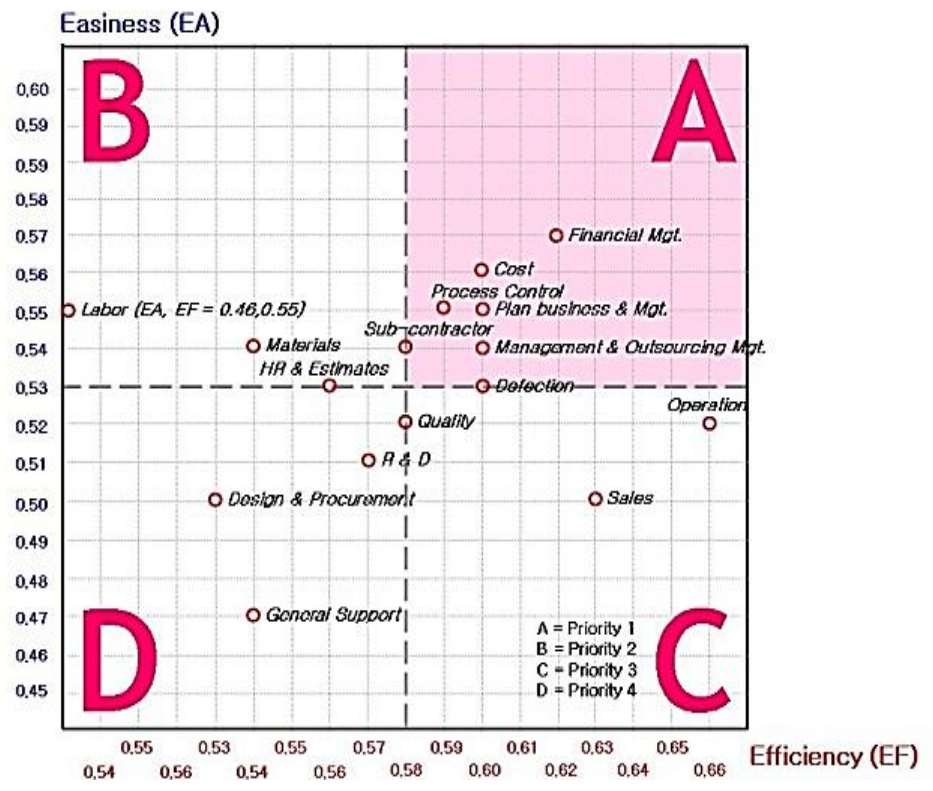

Figure 2. Application Priority for Sequential BPM Model.

\section{Conclusion}

We finally suggested the definition of BPM model and a sequential application plan for business process model. The details are as below:

In order to analyze the peculiarity of construction firms' business process and adopt business process management related to construction firm's strategy, we enhanced and visualized business process of internal and external environment. Then we suggested the definition of BPM model which executes and controls people and system, consistently monitors business process and continuously improves. It is expected to realize business efficiency through process improvement and also get rid of inefficient factors since the adoption of business process model.

Finally, we have suggested business priorities for a sequential BPM application by quantitative standards. Efficiency (EF) and Easiness (EA) of applying an BPM model.

\section{References}

1. Howard Smith and Peter Fingar. The Third Wave analysis. (2002)

2. Hammer. The Reengineering Revolution analysis. (1995)

3. Weskw. Design, management and improvement plan for productivity improvement. (2004)

4. B.O. Lee, A study on the Case of Implementing BPM of a Manufacturing Company analysis. (2004)

5. J. H. Choi, A Study of Process Selection and Implementation for Business Process Management analysis.(2006) 